\title{
New record of Laeonereis acuta (Treadwell, 1923) (Nereididae: Polychaeta) in Northeast coast of Brazil
}

Paulo Augusto Zaitune Pamplin ${ }^{1,4}$, Tito César Marques de Almeida ${ }^{2}$ \& Jeremias Pereira da Silva-Filho ${ }^{1}$

Biota Neotropica v7 (n3) - http://www.biotaneotropica.org.br/v7n3/pt/abstract?article +bn00607032007

\author{
Data Received 22/09/06 \\ Revised 24/07/07 \\ Published 01/09/07 \\ ${ }^{1}$ Campus Universitário Profa. Cinobelina Elvas, Universidade Federal do Piauí, \\ Rodovia BR-135 Km 03, CEP 64900-000, Bom Jesus, PI, Brazil \\ ${ }^{2}$ Laboratório de Ecologia Aquática, Centro de Ciências da Terra e do Mar, Universidade do Vale do Itajai, \\ Rua Uruguai 458, CEP 88302-2002, Itajaí, SC, Brazil \\ ${ }^{3}$ Departamento de Biologia, Campus "Min. Petrônio Portela”, Centro de Ciências Naturais (SG-02), \\ Universidade Federal do Piauí, CEP 64049-550, Teresina, PI, Brazil \\ ${ }^{4}$ Corresponding author: Paulo Augusto Zaitune Pamplin, e-mail: pazpamplin@ click21.com.br
}

\section{Abstract}

Pamplin, P.A.Z., Almeida, T.C.M. \& Silva-Filho, J.P. New record of Laeonereis acuta (Treadwell, 1923) (Nereididae: Polychaeta) in Northeast coast of Brazil. Biota Neotrop. Sep/Dez 2007 vol. 7, no. 3 http://www. biotaneotropica.org.br/v7n3/pt/abstract?article+bn00607032007. ISSN 1676-0603.

In the present study, we report the presence of the nereidid polychaete Laeonereis acuta near to the estuarine areas of Parnaíba River, extending its distribution towards the north of the northeastern Brazilian coast.

Keywords: Polychaeta, new record, Laeonereis acuta, distribution, Brazil.

\section{Resumo}

Pamplin, P.A.Z., Almeida, T.C.M. \& Silva-Filho, J.P. Novo registro de Laeonereis acuta (Treadwell, 1923) (Nereididae: Polychaeta) na costa nordestina do Brasil. Biota Neotrop. Sep/Dez 2007 vol. 7, no. 3 http://www. biotaneotropica.org.br/v7n3/pt/abstract?article+bn00607032007. ISSN 1676-0603.

No presente estudo, nós relatamos a presença do poliqueta nereídídeo Laeonereis acuta próximo à região estuarina do rio Parnaíba, ampliando sua distribuição para o litoral norte do nordeste brasileiro.

Palavras-chave: Polychaeta, novo registro, Laeonereis acuta, distribuição, Brasil. 


\section{Introduction}

Nereididae family (previously named as Nereidae) is one of the well known families of errant polychaetes. Main morphological characteristics of this family are: prostomium with a pair of palps and antennae; parapodia generally biramous, except for the first two pairs that are uniramous; peristomium fused with the first body segment and usually with two pairs of tentacular cirri; compound noto- and neurochaetae; notopodia distinct and usually with more flattened lobes and the pharynx distinctively formed by two rings (Santos \& Lana 2001). The ragworms or clam worms, as they are commonly called, are predominantly marine and can reach high density and diversity in estuarine environments. Some nereidid species developed morphological adaptation being able to inhabit both freshwater and semi-terrestrial environments, as observed in the Namanereidinae subfamily (Glasby 1999). There are about 540 described species in the world (Bakken \& Wilson 2005) while in Brazil, Santos \& Lana (2001) pointed out 46 nereidid species.

In this paper, we report a new record of nereidid Laeonereis acuta (Treadwell, 1923) extending its distribution to almost the whole Brazilian coast.

\section{Material and Methods}

In February of 2006, we collected some nereidid specimens from sediment in Parnaíba River ( $2^{\circ} 59^{\prime} 33.9^{\prime \prime} \mathrm{S}$ and $41^{\circ} 48^{\prime} 41.5^{\prime \prime} \mathrm{W}$ ) near the estuarine area. Sediment samples were obtained using a Van Veen grab $\left(377 \mathrm{~cm}^{2}\right)$, and posteriorly washed trough a sieve with $300 \mu \mathrm{m}$. The specimens were preserved in formalin $10 \%$. The material was examined under optic (Olympus CH30, 1000x) and stereomicroscope (Nikon SMZ645, 50x) and identified based on Amaral \& Nonato (1996), Santos \& Lana (2001) and Amaral et al. (2005).

During the collection and sieving procedures, many specimens suffered mechanical injuries and only one entire specimen left over. For this exemplar, total length of body and the number of setigers were measured under stereomicroscope. In addition, the length between prostomium and $1^{\text {st }}$ setiger, and between $1^{\text {st }}$ setiger to $2^{\text {nd }}, 6^{\text {th }}, 13^{\text {th }}$ and $19^{\text {th }}$ setigers, as well as the width of these setigers were measured for other ten fragmentary specimens with the anterior portion of the body in good conditions. Mean values and standard error (SE) of these measurements are presented. Further, some chemical and physical variables ( $\mathrm{pH}$, conductivity, dissolved oxygen concentration and salinity) were measured using a multiprobe equipment HORIBA ${ }^{\circledR}$ model U-10.

Voucher specimens were deposited in Laboratory of Benthos, at the Federal University of Paraná, Brazil, under registration number MCEMBPO 1492.

\section{Results and Discussion}

One hundred and thirteen polychaetes were collected close to macrophyte banks (Eicchornia sp. and Canarana sp.), near the estuarine region of Parnaíba River. Although pharynx (= proboscis) was not extended (due to direct fixation with $10 \%$ formalin), all specimens were identified as Laeonereis acuta (Treadwell 1923) based on morphology of anterior region and by the presence and distribution of papillae on pharynx, conspicuos features of this species, as mentioned by Amaral et al. (2005) (Figure 1). Hartman (1945) and Pettibone (1971) considered this species a junior synonymy of Laeonereis culveri (Webster 1880) distributed from Florida to Uruguay. Posteriorly, they were separated once again by Orensanz \& Gianuca (1974) by differences in the proportion between the posterior notopodial lobes and reproductive aspects. According to these authors, L. culveri refers to the species distributed in subtropical region of North America, while L. acuta occurs in South America.

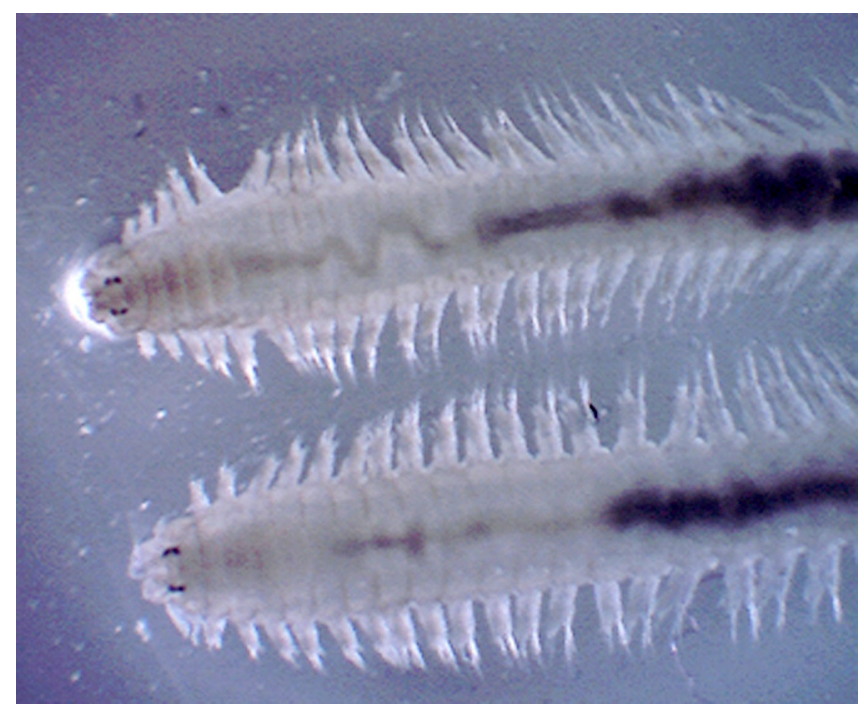

Figure 1. Anterior region of two specimens of Laeonereis acuta with the proboscis not everted.

Figura 1. Região anterior de dois espécimes de Laeonereis acuta com a probóscide não evertida.

We counted 106 setigers on the specimen that was complete, which was $23 \mathrm{~mm}$ long and $1.5 \mathrm{~mm}$ wide. The mean length from prostomium to the $1^{\text {st }}$ setiger was $3.34 \pm 0.02 \mathrm{~mm}$, between the $1^{\text {st }}-2^{\text {nd }}$ setigers $0.18 \pm 0.1 \mathrm{~mm}, 1^{\text {st }}-6^{\text {th }}$ setigers $0.82 \pm 0.04 \mathrm{~mm}, 1^{\text {st }}-13^{\text {th }}$ setigers $2.29 \pm 0.04 \mathrm{~mm}$ and $1^{\mathrm{st}}-19^{\text {th }}$ setigers $3.74 \pm 0.14 \mathrm{~mm}$. The mean width of $2^{\text {nd }}, 6^{\text {th }}, 13^{\text {th }}$ and $19^{\text {th }}$ setigers were $0.64 \pm 0.02 \mathrm{~mm}, 0.83 \pm 0.03 \mathrm{~mm}$, $0.73 \pm 0.02 \mathrm{~mm}$ and $0.65 \pm 0.02 \mathrm{~mm}$, respectively.

Laeonereis acuta is an abundant polychaete in intertidal areas and sandy beaches. As others nereidids, this species is primarily omnivorous and an important link in marine food web, being preyed on by fishes, shorebirds and others invertebrates (Botto et al. 1998, Ieno et al. 2000, Palombo et al. 2004). In addition to the ecological importance $L$. acuta has been used as indicator in many studies of stressed environments (Geracitano et al. 2002, 2004).

In our investigation, L. acuta was collected in shallow areas ( $<0.5$ meters), with $\mathrm{pH}$ ranging from 8.24 to 9.20 (8.68 \pm 0.36$)$ and conductivity relatively low $\left(40.83 \pm 0.98 \mathrm{~ms}^{\mathrm{cm}} \mathrm{cm}^{-1}\right)$. As expected for summer, the temperature was high $\left(28.92 \pm 0.10^{\circ} \mathrm{C}\right)$ and the water was well oxygenated $\left(6.53 \pm 0.71 \mathrm{mg} . \mathrm{L}^{-1}\right)$. In the delta area of Parnaíba River, the specimens of L. acuta were collected in salinity zero. According to Rizzo \& Amaral (2001), this species tolerates high salinity variation.

According to Orensanz \& Gianuca (1974), Laeonereis acuta occurs from Pensinsula de Valdés - Argentina to Recife, in Northeast Brazil. Our registration of L. acuta near to the estuarine region of Parnaíba River, Piauí State, extends the range of distribution to the north.

\section{Acknowledgments}

We are grateful to CODEVASF for financial support.

\section{References}

AMARAL, A.C.Z. \& NONATO, E.F. 1996. Annelida Polychaeta: características, glossário e chaves para famílias e gêneros da costa brasileira. Editora da UNICAMP, Campinas. 
AMARAL, A.C.Z., RIZZO, A.E. \& ARRUDA, E.P. (Orgs.) 2005. Manua de Identificação dos Invertebrados Marinhos da Região Sudeste-Sul do Brasil (Volume 1). EDUSP, São Paulo.

BAKKEN, T. \& WILSON, R.S. 2005. Phylogeny of nereidids (Polychaeta, Nereididae) with paragnaths. Zool. Scr. 34(5):507-547.

BOTTO, F., IRIBARNE, O., MARTINEZ, M., DEHLEY, K. \& CARRETE, M. 1998. The effect of migratory shorebirds on the benthic species of three southwestern Atlantic Argentinean estuaries. Estuaries 21(4B):700-709.

GERACITANO, L.A., MONSERRAT, J.M. \& BIANCHINI, A. 2002 Physiological and antioxidant enzyme responses to acute and chronic exposure of Laeonereis acuta (Polychaeta, Nereididae) to copper. J. Exp. Mar. Biol. Ecol. 277:145-156.

GERACITANO, L.A., MONSERRAT, J.M. \& BIANCHINI, A. 2004.Oxidative stress in Laeonereis acuta (Polychaeta, Nereididae): environmental and seasonal effects. Mar. Environ. Res. 58:625-630.

GLASBY, C.J. 1999. The Namanereidinae (Polychaeta: Nereididae). Part 2, cladistic biogeography. Rec. Aust. Mus. 25:131-144.

HARTMAN, O. 1945. The marine annelids of North Carolina. Duke Univ. Mar. St. Bull. 2:1-51.

IENO, E.N., MARTIN, P.J. \& BASTIDA, R. 2000. Estimation of size classes in Laeonereis acuta (Polychaeta: Nereididae) based on jaw length and body width usable in trophic studies. Bull. Mar. Sci. 67(1):39-43

ORENSANZ, J.M \& GIANUCA, N.M. 1974. Contribuição ao conhecimento dos anelídeos poliquetas do Rio Grande do Sul, Brasil. I. Lista sistemática preliminar e descrição de três novas espécies. Comun. Mus. Ciênc. 4:1-37.

PALOMBO, G., BOTTO, F., NAVARRO, D., ESCAPA, M. \& IRIBARNE O. 2004. The predator-prey interaction between migratory shorebirds and the polychaete Laeonereis acuta is modified by burrowing crabs. Mar. Biol. 145(4):211-228.

PETTIBONE, M.H. 1971. Revision of species referred to Leptonereis, Nicon, and Laeonereis (Polychaeta: Nereididae). Smithson. Contrib. Zool. 104:1-53.

RIZZO, A.E. \& AMARAL, A.C.Z. 2001. Environmental variables and intertidal beach annelids of São Sebastião Channel (State of São Paulo, Brazil). Rev. Biol. Trop. 49(3-4):849-857.

SANTOS, C.S.G \& LANA, P.C. 2001. Nereididae (Annelida, Polychaeta) da costa nordeste do Brasil. II. Gêneros Namalycastis, Ceratocephale, Laeonereis e Rullierinereis. Iheringia (Sér. Zool.) 91:137-149.

TREADWELL, A.L. 1923. Two new species of polychaetous annelids of the genus Nereis from Brazil. Revta Mus. Paul. 13:1237-1243. 
